\title{
Corrigendum: Seasonal Variability in Near-bed Environmental Conditions in the Vazella pourtalesii Glass Sponge Grounds of the Scotian Shelf
}

\author{
Ulrike Hanz ${ }^{1 *}$, Lindsay Beazley ${ }^{2}$, Ellen Kenchington ${ }^{2}$, Gerard Duineveld ${ }^{1}$, \\ Hans Tore Rapp ${ }^{3 \dagger}$ and Furu Mienis ${ }^{1}$ \\ ${ }^{1}$ Department of Ocean Systems, NIOZ Royal Netherlands Institute for Sea Research, Den Burg, Netherlands, ${ }^{2}$ Fisheries and \\ Oceans Canada (DFO), Bedford Institute of Oceanography, Dartmouth, NS, Canada, ${ }^{3}$ Department of Biological Sciences \\ and K.G. Jebsen Centre for Deep-sea Research, University of Bergen, Bergen, Norway
}

Keywords: Vazella pourtalesii, sponge ground, environmental conditions, storm events, particle flux, Scotian Shelf

\section{A Corrigendum on}

Seasonal Variability in Near-bed Environmental Conditions in the Vazella pourtalesii Glass Sponge Grounds of the Scotian Shelf

by Hanz, U., Beazley, L., Kenchington, E., Duineveld, G., Rapp, H. T., and Mienis, F. (2021). Front. Mar. Sci. 7:597682. doi: 10.3389/fmars.2020.597682

\section{OPEN ACCESS}

Edited and reviewed by:

Chiara Romano,

Spanish National Research

Council, Spain

${ }^{*}$ Correspondence:

Ulrike Hanz

Ulrike.hanz@nioz.nl

${ }^{\dagger}$ Deceased

Specialty section:

This article was submitted to

Deep-Sea Environments and Ecology, a section of the journal

Frontiers in Marine Science

Received: 17 April 2021

Accepted: 22 April 2021

Published: 14 May 2021

Citation:

Hanz U, Beazley L, Kenchington E, Duineveld G, Rapp HT and Mienis F

(2021) Corrigendum: Seasonal Variability in Near-bed Environmental Conditions in the Vazella pourtalesii Glass Sponge Grounds of the Scotian Shelf. Front. Mar. Sci. 8:696777. doi: 10.3389/fmars.2021.696777
In the original article, there was a mistake in Figure 6 as published. Due to a database error the flux data shown in Figures 6F, G were presented as $\mathrm{mg} \mathrm{day}^{-1}$ instead of $\mathrm{mg} \mathrm{day}{ }^{-1} \mathrm{~m}^{2}$. The corrected Figure 6 appears below.

Because of the database error related to data presented in Figure 6, average mass and carbon fluxes also need to be adapted in the text.

A correction has been made to the Results and Sediment Trap section:

The vertical mass flux during the deployment period was on average $3166 \pm 3421 \mathrm{mg} \mathrm{m}^{-2}$ day $^{-1}$ (Figure 6F), while the average carbon flux was $100 \pm 72 \mathrm{mg} \mathrm{C} \mathrm{m}^{-2}$ day $^{-1}$ (Figure 6G). Highest vertical mass flux, i.e., $12,390 \mathrm{mg} \mathrm{m}^{-2}$ day $^{-1}$, was observed in the period from December 2017 to January 2018. Highest carbon flux was likewise found in December/January coinciding with the winter storm event $\left(281 \mathrm{mg} \mathrm{C} \mathrm{m}^{-2} \mathrm{day}^{-1}\right.$, Figure 6). The C:N ratio was on average 8.3 \pm 0.2 , ranging from 7.8 to 8.6 (Figure $6 \mathrm{~B}$ ) and the $\delta^{15} \mathrm{~N}$ was $6.7 \pm 0.4 \%$, ranging from 6.2 to $7.3 \%$ o (Figure 6C). The $\delta^{13} \mathrm{C}$ ratio ranged from -23.3 to $-22.8 \%$ with an average of $-23 \pm 0.1 \%$ o (Figure 6D). The Chl- $a$ concentration was on average $2.1 \pm 1.1 \mathrm{mg} \mathrm{l}^{-1}$, with an average Chl- $a$ : Phaeo ratio of $0.00069 \pm 0.00077$ (Figure 6E). The largest peak in Chl- $a\left(4.05 \mathrm{mg} \mathrm{l}^{-1}\right)$, being two times higher than the average Chl- $a$ concentration, was observed in March/April, indicating the arrival of fresh phytodetritus at the seafloor, which occurred after the second storm event in March.

A correction has been made to the Discussion in the Food Supply section Paragraph 1:

Sponges are very efficient filter feeders and feed on particulate as well as dissolved resources (Reiswig, 1971; Pile and Young, 2006). While the average daily carbon flux in the near-bed sediment trap was $100 \pm 72 \mathbf{~ m g ~ C ~ m}^{-2}$ day $^{-1}$ during the deployment period, carbon flux was highly variable and peaked in December/January $\left(281 \mathbf{~ m g ~ C ~ m}^{-2} \mathbf{d a y}^{-1}\right)$ and March/April (130 $\left.\mathbf{~ g ~ C ~ m}^{-2} \mathbf{d a y}^{-1}\right)$. During the December peak no major fluctuations in temperature, salinity or DO concentration were observed, likely indicating that the organic matter is not delivered from the surface but rather due to resuspension events inside the bottom boundary layer. Even though this winter event was characterized by a high carbon flux, mainly degraded organic matter was resuspended as shown by 


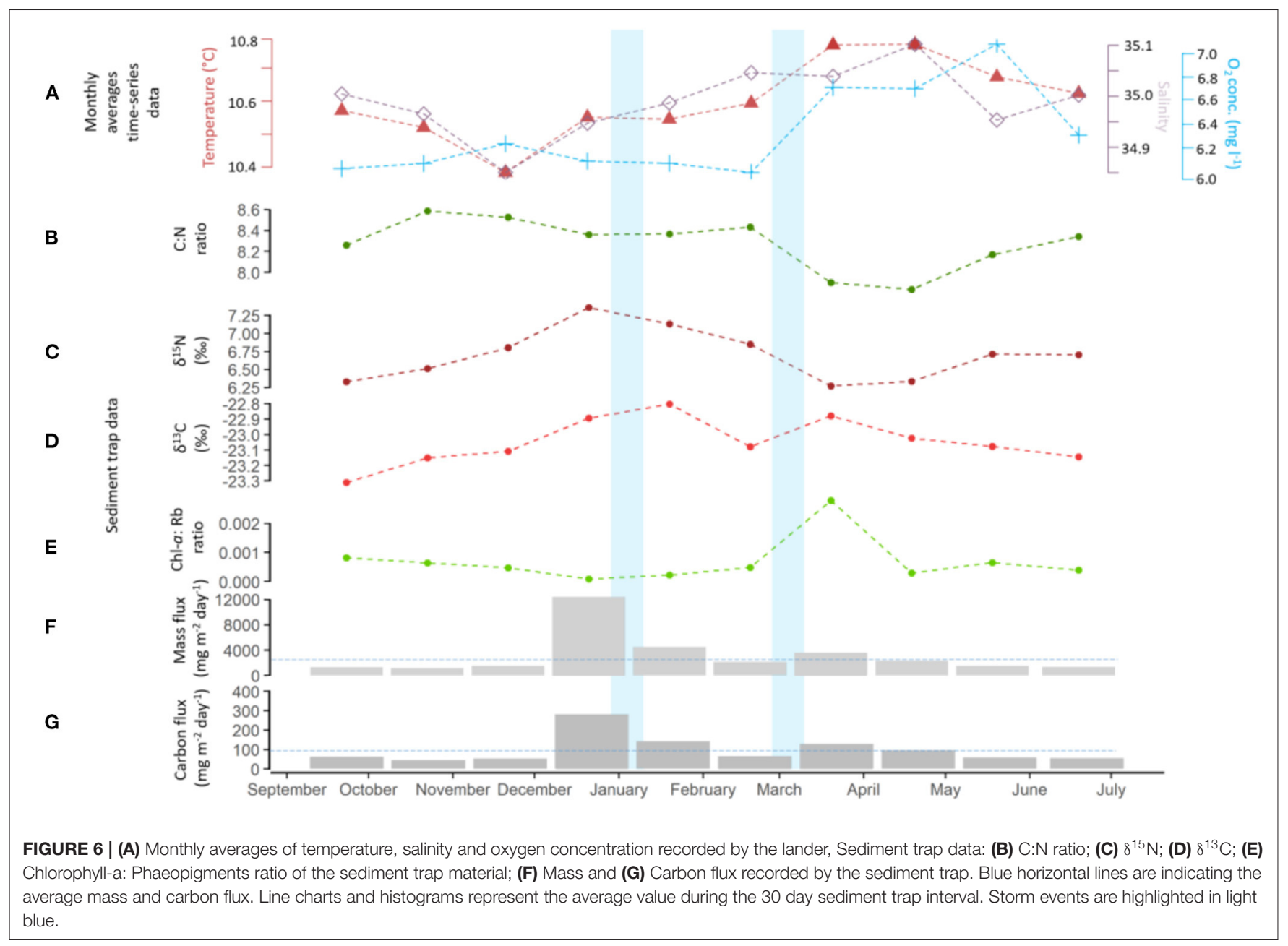

the low concentration of Chl- $a$ and a high C:N ratio (Figure 6), likely related to resuspension and lateral transport of more degraded material from the seafloor. Hill and Bowen (1983) calculated that a current speed of $0.15 \mathrm{~m} \mathrm{~s}^{-1}$ is required to resuspend the coarser sand, whereas fine sand and mud is transported at a speed of $0.11 \mathrm{~m} \mathrm{~s}^{-1}$. Current speed as measured in this study would be sufficient to resuspend coarse sediment during $31 \%$ of the time and $56 \%$ for the finer fraction. This was also apparent in the ADCP turbidity data (Figure 5) which showed an almost permanent turbid layer close to the bottom. The video recordings showed that during storm-induced resuspension events, particularly the winter event, particles stayed in resuspension for several days, which was however not detected in the acoustic backscatter data of the ADCP, implying that turbidity close to the bottom might be even more persistent. This could possibly be due to the particle size of the particles in resuspension, whereby the finer particles are not resolved by measurements of the ADCP (Bunt et al., 1999).
A correction has been made to the Discussion in the Food Supply section Paragraph 3

Taking the estimated carbon demand of a deep-water glass sponge reef (ca. $160 \mathrm{~m}$ depth, $\sim 10^{\circ} \mathrm{C}$ ) at the Canadian coast (1800-4100 $\mathrm{mg} \mathrm{C} \mathrm{m}^{-2}$ day $^{-1}$, Kahn et al., 2015), the carbon derived from the vertical flux would provide on average approximately $<8 \%$ of the required carbon demand. Ex situ experiments have shown that in the Canadian sponge reefs carbon consumption was much higher $\left(360 \mathrm{mg} \mathrm{m}^{-2}\right.$ day $\left.^{-1}\right)$, compared to the average carbon flux $\left(100 \mathrm{mg} \mathrm{m}^{-2}\right.$ day $\left.^{-1}\right)$, showing that the carbon demand of the Vazella grounds will not be satisfied (Bart et al., 2020). A potential carbon deficit may be alleviated from the resuspended organic-rich sediment itself (Grant et al., 1987), but also from the filtration of bacteria and uptake of DOC from the water column (Bart et al., 2020).

The authors apologize for this error and state that this does not change the scientific conclusions of the article in any way. The original article has been updated. 


\section{REFERENCES}

Bart, M. C., Mueller, B., Rombouts, T., Van De Ven, C., Tompkins, G. J., Osinga, R., et al. (2020). Dissolved organic carbon (DOC) is essential to balance the metabolic demands of North-Atlantic deep-sea sponges. bioRxiv [preprint] doi: 10.1101/2020.09.21.305086

Bunt, J. A., Larcombe, P., and Jago, C. F. (1999). Quantifying the response of optical backscatter devices and transmissometers to variations in suspended particulate matter. Continental Shelf Res. 19, 1199-1220. doi: 10.1016/s0278-4343(99)00018-7

Grant, J., Volckaert, F., and Roberts-Regan, D. L. (1987). Resuspendable organic matter in Nova Scotian shelf and slope sediments. Continental Shelf Res. 7, 1123-1138. doi: 10.1016/0278-4343(87)90102-6

Hill, P. R., and Bowen, A. J. (1983). "Modern Sediment Dynamics at the shelfslope Boundary off Nova Scotia," in The Shelfbreak: Critical Interface on Continental Margins: eds D. J. Stanley and G. T. Moore (Tulsa: Society Economic Paleontologists Mineralogists Special Publication 33), 265-276. doi: $10.2110 /$ pec.83.06.0265
Kahn, A. S., Yahel, G., Chu, J. W., Tunnicliffe, V., and Leys, S. P. (2015). Benthic grazing and carbon sequestration by deep-water glass sponge reefs. Limnol. Oceanography 60, 78-88. doi: 10.1002/lno.10002

Pile, A. J., and Young, C. M. (2006). The natural diet of a hexactinellid sponge: benthic-pelagic coupling in a deep-sea microbial food web. Deep Sea Res. Part I: Oceanographic Res. Papers 53, 1148-1156. doi: 10.1016/j.dsr.2006.0 3.008

Reiswig, H. M. (1971). Particle feeding in natural populations of three marine demosponges. Biol. Bull. 141, 568-591. doi: 10.2307/154 0270

Copyright (c) 2021 Hanz, Beazley, Kenchington, Duineveld, Rapp and Mienis. This is an open-access article distributed under the terms of the Creative Commons Attribution License (CC BY). The use, distribution or reproduction in other forums is permitted, provided the original author(s) and the copyright owner(s) are credited and that the original publication in this journal is cited, in accordance with accepted academic practice. No use, distribution or reproduction is permitted which does not comply with these terms. 